\title{
A Bacterial Endophyte, Pseudomonas brassicacearum YC5480, Isolated from the Root of Artemisia sp. Producing Antifungal and Phytotoxic Compounds
}

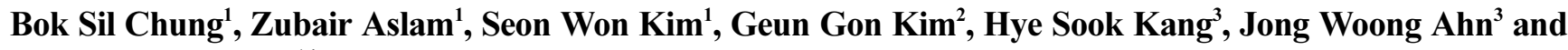 \\ Young Ryun Chung ${ }^{1 *}$ \\ ${ }^{1}$ Division of Applied Life Science (BK 21), PMBBRC \& EB-NCRC, Gyeongsang National University, Jinju 660-701, Korea \\ ${ }^{2}$ Department of Research \& Development, JGreen Inc., Changnyung 635-806, Korea \\ ${ }^{3}$ Research Institute of Marine Science \& Technology, Division of Marine Environment \& Bioscience, Korea Maritime University, \\ Busan 606-791, Korea
}

(Received on February 11, 2008; Accepted on September 11, 2008)

An endophytic bacterial strain YC5480 producing antifungal and phytotoxic compounds simultaneously was isolated from the surface sterilized root of Artemisia sp. collected at Jinju area, Korea. The bacterial strain was identified as a species of Pseudomonas brassicacearum based on its 16S rRNA gene sequence analysis and physiological and biochemical characteristics. The seed germination and growth of monocot and dicot plants were inhibited by culture filtrate (1/10-strength Tryptic Soy Broth) of the strain. The germination rate of radish seeds in the culture filtrate differed in various culture media. Only $20 \%$ of radish seeds germinated in the culture media of 1/2 TSB for 5 days incubation. Mycelial growth of fungal pathogens, Colletotrichum gloeosporioides, Fusarium oxysporum and Phytophthora capsici was also inhibited by the culture filtrate of the strain YC5480. An antifungal compound, KS-1 with slight inhibitory activity of radish seed germination at $1,000 \mathrm{ppm}$ and a seed germination inhibitory compound, KS-2 without suppression of fungal growth were produced simultaneously in TSB. The compounds KS-1 and KS-2 were identified to be 2,4-diacetylphloroglucinol (DAPG) and 2,4,6-trihydroxyacetophenone (THA), respectively.

Keywords : antifungal, 2,4-diacetylphloroglucinol, Pseudomonas brassicacearum, phytotoxic, 2,4,6-trihydroxyacetophenone

Endophytic bacteria have been isolated from a variety of plants and shown to have a number of beneficial effects on the host plant. The associations between bacteria and hosts such as increase of nitrogen fixation, improvement of seed germination and seedling growth, enhancement of nutrient availability, and biocontrol of fungal infections have been reported extensively (Compant et al., 2005; Elbeltagy et al.,

\footnotetext{
*Corresponding author.

Phone) +82-55- 751-5945, FAX) +82-55-759-0187

E-mail)yrchung@gnu.ac.kr
}

2001; Kuklinsky-Sorbal et al., 2004; Nejad and Johnson, 2000; Rosenblueth and Esperanza, 2006). Many isolates of Pseudomonas exist within the plant as endophytes, gain some physical protection and actively interact with the host plant for the benefit of both organisms (Rosenblueth and Esperanza, 2006). The strains of Pseudomonas fluorescens, $P$. corrugata and $P$. putida were most frequently isolated as endophytes and rhizosphere bacteria (Garbeva et al., 2001; Slininger and Shea-Andersh, 2005; Suzuki et al., 2003).

In many cases, these bacteria are known to be beneficial to the host organisms and even potential sources of plant disease resistance against bacterial and fungal pathogens (Benhamou et al., 1996; Misaghi and Donndelinger, 1990; Ryu et al., 2003). However, it was frequently found that some endophytic bacteria including Pseudomonas spp. also damage to the host plants by inhibiting seed emergence, plant height and the growth of plant seedlings, possibly through the production of certain metabolites (van Peer et al., 1990; Sturz and Christie, 1996).

A biological control agent, Pseudomonas fluorescens, against wheat take-all root disease has been observed to produce two metabolites, antifungal compound, 2,4-diacethylphloroglucinol (DAPG) and seed germination inhibitory (phytotoxic) compound, 2,4,6-trihydroxyacetophenone (THA) that is possibly a precursor of DAPG in cultivation liquid medium (Slininger and Shea-Andersh, 2005). The production of other antifungal compound, phenazine-1-carboxylic acid (PCA) has been implicated in the phytotoxicity of $P$. fluorescens on the germination of treated wheat seeds (Slininger et al., 1996; Thomashow and Weller, 1988). A strain of Pseudomonas chlororaphis O6 which inhibits the growth of Fusarium culmorum and induces systemic disease resistance against a bacterial soft-rot pathogen, Erwinia carotovora subsp. carotovora by production of PCA also inhibited seed germination of wheat and barley seeds by seed coating (Kang et al., 2007). The high concentration of the phytotoxic compounds in production cultures of the biological control agents induces phytotoxicity in treated 
plant seeds. Thus it may be very important to minimize the production of phytotoxic metabolites by optimization of carbon and nitrogen sources for the development of manufacturing strategies to supply commercial inoculants (Slininger et al., 1996; Slininger and Shea-Andersh, 2005).

In this study we isolated an endophytic bacterium YC5480 showing both antifungal and phytotoxic activities during screening of biocontrol agents against fungal diseases. We describe here the identification and activity of the strain and characterization of the antifungal and phytotoxic substances produced by this strain.

\section{Materials and Methods}

Isolation of endophytic bacteria. In the process of screening biological control agents for plant-fungal pathogens, endophytic bacteria were isolated from the plant samples, especially roots of Artemisia sp. collected at Jinju area, Korea (Table 1). The roots were rinsed with tap water and surface sterilized with $1.0 \% \mathrm{NaOCl}$ for $10 \mathrm{~min}$ and with $70 \%$ ethanol for about 10 seconds. Root pieces were rinsed again in sterile distilled water (DW), blotted dry on sterile filter paper, placed on 1/10-strength Tryptic Soy Agar (TSA, Difco) and incubated at $28^{\circ} \mathrm{C}$ for bacterial growth to check the surface contamination. After confirmation of the surface sterility of root segments, $1.0 \mathrm{~g}$ of dried plant root was ground in $9.0 \mathrm{ml}$ of phosphate buffer $(\mathrm{pH} 7.2)$ with a sterile mortar and pestle. Serial dilutions were made using phosphate buffer and $100 \mu \mathrm{l}$ of $10^{3}-10^{5}$ dilutions was applied on the $1 / 10 \mathrm{TSA}$ plates and incubated at $28^{\circ} \mathrm{C}$ for 3 days (McInroy and Kloepper, 1995). Among growing bacterial colonies, only bacterial strains having antifungal and/ or seed germination inhibitory activity were selected and maintained on $1 / 10 \mathrm{TSA}$ at $4^{\circ} \mathrm{C}$ for further experiments.

Antifungal activity tests. For the selection of the bacterial strains with antifungal activity, confrontation bioassay was used. The agar plug $(5 \mathrm{~mm})$ of actively growing fungal pathogens was placed in the center of the 1/10 TSA and Potato Dextrose Agar (PDA, Difco) media with streaking of bacterial isolates around the fungal plug at the same distance. Antifungal activity of culture filtrate or purified compounds was also tested by confrontation bioassay using paper disks $(5 \mathrm{~mm})$ loaded with $200 \mu$ l of the culture filtrate or solutions of compounds on PDA media. The culture filtrate of strains was prepared using 1/10-strength Tryptic Soy Broth (TSB, Difco). Each strain isolated from 1/10 TSA plates was inoculated in $3 \mathrm{ml}$ broth of $1 / 10 \mathrm{TSB}$ and incubated for 3 days at $30^{\circ} \mathrm{C}$ on a rotary shaker (approximately $150 \mathrm{rpm}$ ). The cell suspension was centrifuged at $7,520 \times g$ for $15 \mathrm{~min}$, and then the supernatant was filtered through $0.45 \mu \mathrm{m}$ Minisart syringe end filters (Sartorius, UK
$\&$ Ireland) for the activity tests. The antifungal activity against Colletotrichum gloeosporioides KCTC 6169, Fusarium oxysporum KCTC 16909, and Phytophthora capsici KACC 40157 was examined after 5 days of incubation at $30^{\circ} \mathrm{C}$ by measuring zones of inhibition between the edge of the bacterial colony and growing fungal mycelia on PDA. The strains having KCTC and KACC accession numbers were obtained from the Korean Collection for Type Cultures (KCTC), Daejeon, Korea and Korea Agricultural Culture Collection (KACC), Suwon, Korea.

Seed germination inhibitory activity assay. For the test of seed germination inhibitory activity, the culture filtrate was applied to radish (Raphanus sativus) seeds surface-sterilized with $1 \% \mathrm{NaOCl}$ for $5 \mathrm{~min}$. Five seeds of radish in 3 replications were placed on a piece of sterile Kim-Wipe tissue $(2 \times 2 \mathrm{~cm})$ soaked with $0.5 \mathrm{ml}$ culture filtrate in a plastic plate. The plates were incubated for 3-5 days at room temperature under normal day light. The percent ratio of radish seed germination and the growth of sprouts were measured. Following crop seeds were treated with the culture filtrate for 5 days at room temperature as described previously to know the seed germination inhibition spectrum of the bacterial filtrate; wheat (Triticum aestivum), barley (Hordeum vulgare), rice (Oryza sativa), soybean (Glycine max), pepper (Capsicum annuum) and lettuce (Lactuca sativa). All crop seeds were purchased from Nongwoo Bio Co. Ltd., Korea.

Biochemical and physiological characterization of a bacterial strain. Among endophytic bacterial strains, the strain YC5480 (KCTC 10957BP) having antifungal and seed germination inhibitory activities was identified on the basis of biochemical, physiological and molecular characteristics according to "Current Protocols in Molecular Biology" (Ausubel et al., 1995) and "Chemical Methods in Prokaryotic Systems" (Goodfellow and O'Donell, 1994). Carbohydrate assimilation was determined by using API ID $32 \mathrm{E}$ and API ID32 STREP at $30^{\circ} \mathrm{C}$ according to the instructions of the manufacturer (bioMérieux). Cell morphology was observed under a transmission electron microscope (Hitachi, model H-600) with cells grown for one day at $28^{\circ} \mathrm{C}$ on $1 / 10 \mathrm{TSA}$.

DNA extraction and phylogenetic analysis of 16S rRNA gene sequence. Extraction of genomic DNA from the strain YC5480 was done using commercial genomic DNA extraction kit (Core Biosystem, Korea). The 16S rRNA gene was PCR amplified from a small amount of purified genomic DNA by using a set of primers 27F and 1492R and the obtained PCR product was purified and sequenced according to Chung et al. (Chung et al., 1999). The 16S 
rRNA gene sequences were compiled using SeqMan software (DNASTAR). The NCBI/EMBL/DDBJ accession number for 16S rRNA gene sequence of strain YC5480 (= KCTC 10957BP) is EU195810. For phylogenetic analysis, the 16S rRNA gene sequences of related taxa were obtained from the GenBank database. The multiple alignments were performed by CLUSTAL_X program (Thompson et al., 1997). Gaps were edited in the BioEdit program (Hall, 1999). The evolutionary distances were calculated using the Kimura two-parameter model (Kimura, 1983). The phylogenetic trees were constructed by using a neighborjoining method (Saitou and Nei, 1987) in MEGA3 Program (Kumar et al., 2004) with bootstrap values based on 1000 replications (Felsenstein, 1985).

Selection of optimal medium for the production of active metabolites. To select culture media for mass production of antifungal and germination inhibitory compounds, the following culture media were used: 1/2-strength TSB, glucose starch broth (GSB) (soluble starch, 5.0 g; glucose, $5.0 \mathrm{~g}$; aspartic acid, $0.5 \mathrm{~g} ; \mathrm{K}_{2} \mathrm{HPO}_{4}, 0.5 \mathrm{~g} ; \mathrm{MgSO}_{4}, 0.5 \mathrm{~g}$ and $\mathrm{FeSO}_{4}, 0.01 \mathrm{~g}$ in one liter DW), soybean meal flour medium (SMF) (yeast extract, $4.0 \mathrm{~g}$; beef extract, $1.0 \mathrm{~g}$; soluble starch, $20.0 \mathrm{~g}$; soybean meal, $25.0 \mathrm{~g}$; glucose, $5.0 \mathrm{~g} ; \mathrm{K}_{2} \mathrm{HPO}_{4}, 0.1$ g; $\mathrm{NaCl}, 2.0 \mathrm{~g}$ in one liter DW), soytone glucose broth (SGB) (glucose, $15.0 \mathrm{~g}$; soytone, $15.0 \mathrm{~g}$, yeast extract, 5.0 g; casamino acid, $1.0 \mathrm{~g} ; \mathrm{K}_{2} \mathrm{HPO}_{4}, 0.1 \mathrm{~g} ; \mathrm{NaCl}, 2.0 \mathrm{~g}$ and $\mathrm{FeSO}_{4}\left(\mathrm{NH}_{4}\right)_{2} \mathrm{SO}_{4} \cdot 6 \mathrm{H}_{2} \mathrm{O}, 0.05 \mathrm{~g}$ and $\mathrm{MgSO}_{4} \cdot 7 \mathrm{H}_{2} \mathrm{O}, 0.2 \mathrm{~g}$ in one liter DW), Czapek-dox broth (CDB) (saccharose, 30.0 g; $\mathrm{NaNO}_{3}, 3.0 \mathrm{~g} ; \mathrm{K}_{2} \mathrm{HPO}_{4}, 1.0 \mathrm{~g} ; \mathrm{MgSO}_{4}, 0.5 \mathrm{~g} ; \mathrm{KCl}, 0.5 \mathrm{~g}$ and $\mathrm{FeSO}_{4} 0.01 \mathrm{~g}$ in one liter DW) and M523 broth (sucrose, $1.0 \mathrm{~g}$; casamino acid, $8.0 \mathrm{~g}$; yeast extract, $4.0 \mathrm{~g}$ and $\mathrm{MgSO}_{4}, 0.3 \mathrm{~g}$ in one liter DW). Each medium (500 ml) was inoculated with the $5 \mathrm{ml}$ culture inoculum of bacterial cells grown overnight and incubated for 3 days at $30^{\circ} \mathrm{C}$ on a rotary shaker (approximately $150 \mathrm{rpm}$ ).

Isolation of antifungal and seed germination inhibitory compounds. After 5 days shaking incubation of the strain YC5480 in 1/2 TSB, the culture broth (10 liters) was centrifuged at $7,520 \times g$ at $4^{\circ} \mathrm{C}$ for $15 \mathrm{~min}$ to remove the bacterial cells. The cell-free supernatant was concentrated about ten-fold under reduced pressure and extracted twice with ethyl acetate. The extracts were combined and concentrated under reduced pressure to give $2.5 \mathrm{~g}$ of brown oil. A solution of the oil in $\mathrm{CH}_{2} \mathrm{Cl}_{2}$ was applied onto a column of silica gel (50 g), which was eluted stepwise with $300 \mathrm{ml}$ of $\mathrm{CH}_{2} \mathrm{Cl}_{2}$-methanol 95:5 (fraction 1.1), $\mathrm{CH}_{2} \mathrm{Cl}_{2}$ methanol 90:10 (fraction 1.2), and methanol (fraction 1.3). Fraction 1.1 was dissolved in a small volume of methanol, applied on a Sephadex LH-20 column (i.d. $2.5 \times 80 \mathrm{~cm}$, Pharmacia Biotech.), and eluted with methanol. The active fractions were concentrated under reduced pressure to give $0.9 \mathrm{~g}$ of brown oil. The oil was further separated by silica gel MPLC [LiChroprep Si 60, Merck, hexane-EtOAc-i$\mathrm{PrOH}(60: 5: 1), 5 \mathrm{ml} / \mathrm{min}$, detection at $254 \mathrm{~nm}$ ] to yield compounds, KS-1 (250 mg) and KS-2 (50 mg).

Characterization of antifungal and phytotoxic compounds. UV spectrum was recorded on a Agilent 8453 spectrophotometer and IR spectrum on a Bruker IFS-66/S FTIR spectrometer. ESIMS was obtained on a Agilent 1100LC/MSD trap SL mass spectrometer and HRESIMS was obtained on a high resolution tandem mass spectrometer (JMS-HX110/110A). NMR spectra were measured on a Varian UNITY 500 spectrometer working at $500 \mathrm{MHz}$ for proton and $125 \mathrm{MHz}$ for carbon. The ${ }^{1} \mathrm{H}$ and ${ }^{13} \mathrm{C}$ NMR chemical shifts were referred to $\mathrm{CD}_{3} \mathrm{OD}$ observed at 3.30 ppm and 49.0 ppm, respectively.

GenBank accession. The GenBank accession number for 16S rRNA gene sequence of strain YC5480 (= KCTC $10957 \mathrm{BP})$ is EU195810.

\section{Results}

Identification of the strain YC5480. The bacterial strain YC5480 showing antifungal activity against $C$. gloeosporioides and germination inhibitory activity against radish seeds was isolated from the surface sterilized root of Artemisia sp. (Table 1). The strain was identified as a

Table 1. Inhibitory activity of endophytic bacteria isolated from various plant roots to radish seed germination and mycelial growth of Colletotrichum gloeosporioides

\begin{tabular}{|c|c|c|c|c|c|}
\hline \multirow[t]{2}{*}{ Strains } & \multirow[t]{2}{*}{ Locality } & \multirow[t]{2}{*}{$\begin{array}{l}\text { Host } \\
\text { plant }\end{array}$} & \multicolumn{2}{|c|}{$\begin{array}{c}\text { Inhibition zone } \\
\text { of mycelial } \\
\text { growth }(\mathrm{mm})^{\mathrm{a}}\end{array}$} & \multirow{2}{*}{$\begin{array}{c}\begin{array}{c}\text { Inhibition } \\
\text { of radish } \\
\text { germination }\end{array} \\
1 / 2 \mathrm{TSB}\end{array}$} \\
\hline & & & $1 / 10 \mathrm{TSA}^{\mathrm{c}}$ & $\mathrm{PDA}^{\mathrm{c}}$ & \\
\hline YC5355 & Sacheon & Green tea & $2-3$ & $1-2$ & - \\
\hline YC5456 & Sacheon & Garlic & $1-2$ & 3 & - \\
\hline YC5480 & Jinju & Artemisia & $5-6$ & $9-12$ & ++ \\
\hline YC5497 & Hadong & Lettuce & - & 2 & - \\
\hline YC5501 & Jinju & Lettuce & $2-3$ & - & - \\
\hline YC5507 & Sanchung & $\begin{array}{l}\text { Chinese } \\
\text { Cabbage }\end{array}$ & - & $1-2$ & - \\
\hline YC5554 & Sanchung & Pepper & $2-3$ & - & - \\
\hline
\end{tabular}

${ }^{\text {a Inhibition of mycelial growth was tested by confrontation bioassay at }}$ $28^{\circ} \mathrm{C}$ for 5 days incubation.

${ }^{\text {b}}$ The culture filtrate was used to test the radish seed germination inhibitory activity. Five seeds of radish in three replications were placed on a piece of sterile Kim-Wipe tissue $(2 \times 2 \mathrm{~cm})$ in a plastic plate loaded with $0.5 \mathrm{ml}$ culture filtrate for 3-5 days under normal day light. -; no inhibition, ++; strong inhibition.

${ }^{\mathrm{C}} \mathrm{TSA}=$ Tryptic Soy Agar; PDA=Potato Dextros Agar. 


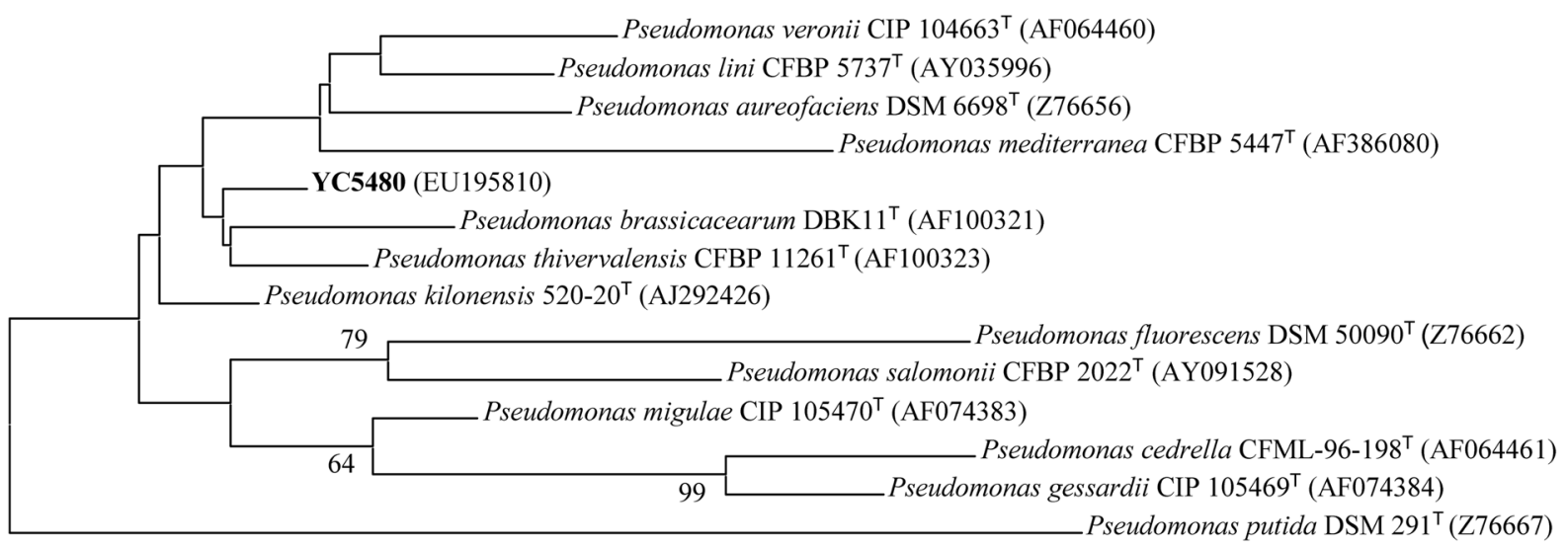

0.01

Fig. 1. Phylogenetic tree constructed from the comparative analysis of 16S rRNA gene sequences showing the relationships of strain YC5480 with Pseudomonas brassicacearum DBK11 ${ }^{\mathrm{T}}$ and other related species. This phylogenetic tree was constructed by using the neighbor-joining method and Jukes \& Cantor evolutionary distance matrix data obtained from unambiguous aligned nucleotides. Bootstrap values (expressed as percentage of 1000 replications) greater than $50 \%$ are shown at the branch points. Bar, 1 substitution per 100 nucleotide position.

species of Pseudomonas brassicacearum based on biochemical and physiological characteristics and its $16 \mathrm{~S}$ rRNA gene sequence and phylogenetic analyses (Fig. 1). The 16S rRNA gene sequence of the strain was most closely related to species of the genus Pseudomonas $(<94.0$ - $>99.0 \%$ sequence similarity), especially to $P$. brassicacearum CFBP $11706^{\mathrm{T}}$ (99.1\%), P. thivervalensis CFBP $11261^{\mathrm{T}}(99.4 \%)$, P. kilonensis $520-20^{\mathrm{T}}(99.4 \%)$ and $P$. putida $\mathrm{PC}^{\mathrm{T}}{ }^{\mathrm{T}}$ (99.1\%). Some other physiological and biochemical characteristics of the strain YC5480 were also very similar to $P$. brassicacearum which are given as following. Gram-negative motile rods, 1.0-2.5 $\mu \mathrm{m}$ in length and about $0.5 \mu \mathrm{m}$ in diameter. Forms mucoid colonies with regular margins when grown on TSA and produces brownorange diffusible pigment at late stationary phase. Growth is strictly aerobic and catalase-positive. It can use 5-bromo4-chloro-3-indolyl-N-acetyl- $\beta$-D-glucosaminide, and Dsorbitol as a single carbon source, but cannot use the following chemicals; L-arabitol, galacturonic acid, 5-bromo3-indoxyl-nonanoate, sodium pyruvate, 4-nitrophenyl- $\beta$-Dglucopyranoside, D-mannitol, D-maltose, adonitol, palatinose, L-tryptophan, 4-nitrophenyl- $\beta$-D-galactopyranoside, D-glucose, D-saccharose (sucrose), L-arabinose, D-arabitol, D-trehalose, D-rhamnose and D-cellobiose.

Seed germination inhibitory activity. The culture filtrate of $P$. brassicacearum YC5480 has inhibitory activity on the germination of all tested crop seeds. The germination rate of barley, radish, pepper, rice, wheat, bean and lettuce was $30,30,30,40,40,50$ and $50 \%$, respectively, comparing to $100 \%$ of the control. The barley, radish and pepper were
Table 2. Inhibition of seed germination of monocotyledonous and dicotyledonous plant species by culture filtrate of Pseudomonas brassicacearum YC5480

\begin{tabular}{ccccc}
\hline \hline \multirow{2}{*}{ Plant species } & \multicolumn{3}{c}{ Germination (\%) } \\
\cline { 3 - 5 } & Days & 1 & 3 & 5 \\
\hline \multirow{3}{*}{ Monocot } & Wheat & 30 & 40 & 40 \\
& Barley & 30 & 30 & 30 \\
& Rice & 10 & 40 & 40 \\
& Radish & 10 & 30 & 30 \\
\hline \multirow{3}{*}{ Dicot } & Bean & 20 & 50 & 50 \\
& Pepper & 30 & 30 & 30 \\
& Lettuce & 50 & 50 & 50 \\
\hline \multirow{3}{*}{} & DW & 100 & 100 & 100
\end{tabular}

${ }^{a}$ The culture filtrate was used to test the inhibitory activity of seed germination of monocot and dicot crops. Five seeds of radish in three replications were placed on a piece of sterile Kim-Wipe tissue $(2 \times 2$ $\mathrm{cm}$ ) in a plastic plate loaded with $0.5 \mathrm{ml}$ culture filtrate for 3-5 days under normal day light. Distilled water (DW) was used as control.

most affected by the culture filtrate with only $30 \%$ of the germination rate after 5 days incubation (Table 2). Effect of different culture media on the germination of radish seeds was determined. The rate of germination differed in various culture media at 20,30, 40 and $70 \%$ in the culture media of 1/2 TSB, Czapek-dox broth, SMF and SGB, respectively, for 5 days incubation. However, the germination of radish seeds was not affected when culture media of M523 and GSB were used (Table 3). The culture filtrate for seed inhibition was most effective when bacteria were cultured at $28^{\circ} \mathrm{C}$, while the low temperatures $\left(15-20^{\circ} \mathrm{C}\right)$ decreased the efficacy of culture filtrate (data not shown). The strength 
Table 3. Effects of culture media on the germination of radish seeds by Pseudomonas brassicacearum YC5480

\begin{tabular}{|c|c|c|c|c|}
\hline \multirow{2}{*}{ Culture Broth ${ }^{\mathrm{b}}$} & \multicolumn{4}{|c|}{ Germination $(\%)^{\mathrm{a}}$} \\
\hline & Days & 1 & 3 & 5 \\
\hline $1 / 2 \mathrm{TSB}$ & & 20 & 20 & 20 \\
\hline M523 & & 100 & 100 & 100 \\
\hline SGB & & 30 & 60 & 70 \\
\hline SMF & & 30 & 40 & 40 \\
\hline GSB & & 100 & 100 & 100 \\
\hline $\mathrm{CDB}$ & & 10 & 30 & 30 \\
\hline DW & & 100 & 100 & 100 \\
\hline
\end{tabular}

${ }^{a}$ The culture filtrate was used to test the inhibitory activity of radish seed germination. Five seeds of radish in three replications were placed on a piece of sterile Kim-Wipe tissue $(2 \times 2 \mathrm{~cm})$ in a plastic plate loaded with $0.5 \mathrm{ml}$ culture filtrate for 3-5 days under normal day light.

${ }^{\text {b}}$ TSB, Tryptic soy broth; SMF, Soybean meal flour broth; SGB, Soytone glucose broth; GSB, Glucose starch broth; CDB, Czapek-dox broth. Distilled water (DW) was used as control.

of culture filtrate in inhibiting seed germination and shoot growth of radish was checked with different dilutions. The culture filtrate without dilution inhibited the shoot growth of radish completely $(100 \%)$ and still had inhibitory activity with 100 times dilution (Fig. 2).

Antifungal and seed germination inhibitory activity of the purified substances. The two substances, KS-1 and KS-2 purified from the culture filtrate of $P$. brassicacearum YC5480 exhibited antifungal and seed germination inhibitory activities. The compound KS-1 inhibited mycelial growth of $C$. gloeosporioides, F. oxysporum, and $P$. capsici at 100 and 1,000 ppm and also inhibited seed germination

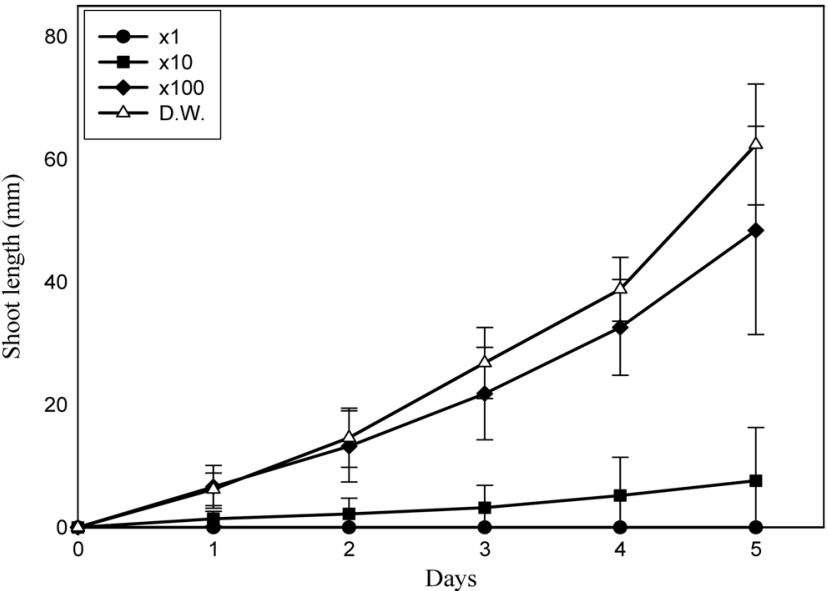

Fig. 2. Inhibition of radish shoot growth by culture filtrate of Pseudomonas brassicacearum YC5480. The culture filtrate was used to test seed germination inhibitory activity. Five seeds of radish in three replications were placed on a piece of sterile KimWipe tissue $(2 \times 2 \mathrm{~cm})$ loaded with $0.5 \mathrm{ml}$ filtrate and shoot length was measured after 5 days incubation under normal day light.

and show the dilution factors of the culture filtrate, shows the deionized water (D.W.) which was used as a control.

of radish slightly at the same concentration. In contrast to KS-1, the compound KS-2 showed only inhibitory activity of seed germination of radish at 100 and 1,000 ppm (Table 4).

Identification of the active substances. Substance KS-1 was isolated as colorless oil which analyzed for $\mathrm{C}_{10} \mathrm{H}_{10} \mathrm{O}_{5}$ by combined FABMS and ${ }^{13} \mathrm{C}$ NMR spectrometry. IR absorptions at 3,413 (broad) and 1,624 $\mathrm{cm}^{-1}$ revealed the presence of hydroxyl(s) and ketonic carbonyl(s), respectively. The

Table 4. Inhibition of mycelial growth of fungal pathogens and radish seed germination by purified compounds KS-1 and KS-2 from the culture filtrate of Pseudomonas brassicacearum YC5480

\begin{tabular}{|c|c|c|c|c|c|}
\hline \multirow{3}{*}{ Compound } & \multirow{3}{*}{$\begin{array}{l}\text { Conc. } \\
(\mathrm{ppm})^{\mathrm{a}}\end{array}$} & \multicolumn{4}{|c|}{ Activity } \\
\hline & & \multicolumn{3}{|c|}{ Inhibition zone $(\mathrm{mm})^{\mathrm{b}}$} & \multirow{2}{*}{$\begin{array}{l}\text { Inhibition of radish seed } \\
\text { germination }(\%)^{\mathrm{c}}\end{array}$} \\
\hline & & $\begin{array}{l}\text { Colletotrichum } \\
\text { gloeosporioides }\end{array}$ & $\begin{array}{l}\text { Fusarium } \\
\text { oxysporum }\end{array}$ & $\begin{array}{l}\text { Phytophthora } \\
\text { capsici }\end{array}$ & \\
\hline \multirow{4}{*}{ KS-1 } & 10 & 0 & 2 & 0 & 7 \\
\hline & 100 & 0 & 4 & 7 & 7 \\
\hline & 1,000 & 3 & 10 & 5 & 13 \\
\hline & 10,000 & 5 & 14 & 13 & 13 \\
\hline \multirow{4}{*}{ KS-2 } & 10 & 0 & 0 & 0 & 7 \\
\hline & 100 & 0 & 0 & 0 & 53 \\
\hline & 1,000 & 0 & 0 & 0 & 47 \\
\hline & 10,000 & 0 & 0 & 1 & 73 \\
\hline
\end{tabular}

${ }^{a}$ Each chemical dissolved in methanol $(200 \mu \mathrm{l})$ was loaded on a $5 \mathrm{~mm}$ paper disk.

${ }^{\mathrm{b}}$ Inhibition of mycelial growth was determined 5 days after incubation on PDA at $30^{\circ} \mathrm{C}$.

${ }^{\mathrm{c}} 0.5 \mathrm{ml}$ of methanol dissolved with each chemical was loaded on a piece of sterile Kim-Wipe tissue $(2 \times 2 \mathrm{~cm})$ and dried. Five seeds of radish in 3 replications were placed on the tissue for 3-5 days under normal day light. 
(A)<smiles>CC(=O)c1c(O)cc(O)c(C(C)=O)c1O</smiles>

(B)

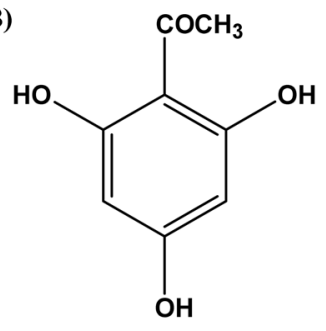

Fig. 3. The chemical structure of (A) KS-1 (2,4-diacetylphloroglucinol) and (B) KS-2 (2,4,6-trihydroxyacetophenone) isolated from the culture filtrate of Pseudomonas brassicacearum YC5480.

NMR data for substance KS-1 showed all of the characteristics of polyphenol. A combination of DEPT, gHSQC, and gHMBC experiments determined the gross structure of substance KS-1 including diacetyl moieties. A literature survey revealed that the proposed structure of substance KS-1 was identical with that of 2,4-diacetylphloroglucinol (DAPG) produced by $P$. fluorescens (Reddi et al., 1969). KS-1 (Fig. 3). FABMS: $m / z 211[\mathrm{M}+\mathrm{H}]^{+}$; ${ }^{1} \mathrm{H}$ NMR $\left(\mathrm{CD}_{3} \mathrm{OD}\right): \delta 5.77(1 \mathrm{H}, \mathrm{s}), 2.60(6 \mathrm{H}, \mathrm{s}) ;{ }^{13} \mathrm{C} \mathrm{NMR}\left(\mathrm{CD}_{3} \mathrm{OD}\right)$ : $\delta$ 205.2(x2), 172.6(x2), 170.2, 104.9(x2), 95.6, 32.9(x2).

The molecular formula of substance KS-2 was deduced as $\mathrm{C}_{8} \mathrm{H}_{8} \mathrm{O}_{4}$ on the basis of combined FABMS and ${ }^{13} \mathrm{C}$ NMR analyses. The spectral data for substance KS-2 were very similar to those obtained for substance KS-1, with the loss of signals for an acetyl group in both ${ }^{1} \mathrm{H}$ and ${ }^{13} \mathrm{C}$ NMR data being the only noticeable difference. A combination of the two-dimensional NMR experiments revealed that one of two acetyl groups in substance KS-1 was missing in substance KS-2. Thus the structure of substance KS-2 was defined as 2,4,6-trihydroxyacetophenone (THA) (Reddi et al., 1969). KS-2 (Fig. 3). FABMS: $m / z$ 169[M+H] $]^{+}{ }^{1} \mathrm{H}$ NMR (CD $\left.\mathrm{CD}_{3} \mathrm{OD}\right): \delta 5.80(2 \mathrm{H}, \mathrm{s}), 2.59(3 \mathrm{H}, \mathrm{s}) ;{ }^{13} \mathrm{C} \mathrm{NMR}$ $\left(\mathrm{CD}_{3} \mathrm{OD}\right): \delta 204.6,166.3(\mathrm{x} 2), 165.9,105.6,95.6(\mathrm{x} 2), 32.7$.

\section{Discussion}

The endophytic bacterial strain, YC5480 isolated from the root of Artemisia sp. with antifungal and phytotoxic activities was identified as $P$. brassicacearum. The species of $P$. brassicacearum was originally isolated from the rhizosphere of Brassica napus and Arabidopsis thaliana in France and some isolates of the species were also found in wheat field soils of two distinct geographic locations in Australia (Achouak et al., 2000; Ross et al., 2000). Some isolates had in vitro antagonism against the take-all fungus of wheat, Gaeumannomyces graminis var. tritici and suppressed take-all in pot trials (Ross et al., 2000). This indicates that isolates of $P$. brassicacearum have potential for use as biological control agent of plant pathogens (Fromin et al., 2001; Ross et al., 2000). However, no

phytotoxic effect was reported on these strains of $P$. brassicacearum in spite of its importance as the biological control agent. The inhibition of seed germination and shoot growth of radish and other crops by the strain of $P$. brassicacearum has been first reported in this study. One strain 520-1 of the species was found to be pathogenic to tomato seedlings with chlorotic leaflets, vascular browning and necrotic lesions (Sikorski et al., 2001). It was frequently found that some bacterial endo- phytic isolates from healthy plants inhibited the growth of plant seedlings in inoculation tests, possibly through the production of certain metabolites (van Peer et al., 1990; Rosenblueth and Martinez-Romero, 2006).

The inhibition of seed germination and shoot growth of all tested crops in the culture filtrate of $P$. brassicacearum YC5480 regardless of monocot or dicot plants indicates that the inhibitory substance may be secreted into the culture media. Some strains of Pseudomonas fluorescens are known to suppress root and shoot growth of a grassy weed and bentgrass by producing peptides, fatty acid esters, a lipopolysaccharide matrix and indole-3-acetic acid (Gurusiddaiah et al., 1994; Suzuki et al., 2003). Recently, seed coating of barley and wheat seeds with Pseudomonas chlororaphis $\mathrm{O} 6$ at the same level as that in field soil was also found to inhibit seed germination by production of phenazine (Kang et al., 2007). The inhibition of radish seed germination by the strain of $P$. brassicacearum YC5480 was higher in the culture media, $1 / 2$ TSB and CDB than other tested media which contained much more nutrients than the former two media. This may be due to the production of more amounts of active compounds KS-1 and KS-2 in these two media with relatively less nutrients than other rich media. The production of antifungal compounds and biocontrol activity of the bacteria is affected by cultivation conditions specially culture media (Bae et al., 2007). An important step in the development of a biological control agent is to determine the culture media for the efficient production of high yields of viable cells without accumulation of toxic compounds to miorobes and plant growth. In addition, the cultivation conditions can be adjusted to optimize best cell activity and minimum production of inhibitory compounds (Slininger and Shea-Andersh, 2005).

Two antifungal and phytotoxic substances KS-1 (DAPG) and KS-2 (THA) were produced simultaneously in the culture broth of $P$. brassicacearum YC5480. The metabolites have also been observed to accumulate in liquid cultures of other pseudomonad strains and THA is likely a precursor or co-product during the biosynthesis of DAPG (Harrison et al., 1993; Shanahan et al., 1993; Slininger and Shea-Andersh, 2005). Both substances purified in this study inhibited the germination of radish seeds as in other studies (Reddi et al., 1969; Slininger and Shea-Andersh, 
2005). The substance DAPG inhibited mycelial growth of fungal pathogens at low concentrations. It is well recognized as a broad-spectrum antifungal substance produced by fluorescent pseudomonads that can control soilborne pathogens in the rhizosphere (Landa et al., 2003; Shanahan et al., 1992; Weller, 2007).

In this study, the strain of $P$. brassicacearum produced a phytotoxic substance THA as well as an antifungal substance DAPG during the cultivation. These results suggest that optimum cultivation conditions of this strain need to be determined to minimize the production of phytotoxic substances and maximize that of viable cell mass for the development as a biological control agent for plant diseases.

\section{Acknowledgements}

This research was supported by a grant from the Korea Research Foundation (KRF-2004-005-C00005) and the project for Technology Innovation \& Development (S1007732), Korea Small \& Medium Business Administration. The scholarships for Bok Sil Chung and Zubair Aslam were supported by the BK 21 program, Ministry of Education, Science and Technology, Korea.

\section{References}

Achouak, W., Sutra, L., Heulin, T., Meyer, J. M., Fromin, N., Degraeve, S., Christen, R. and Gardan, L. 2000. Pseudomonas brassicacearum sp. nov. and Pseudomonas thivervalensis sp. nov., two root-associated bacteria isolated from Brassica napus and Arabidopsis thaliana. Int. J. Syst. Evol. Microbiol. 50:9-18.

Ausubel, F. M., Brent, R., Kingston, R. E., Moore, D. D., Seidman, J. G., Smith, J. A. and Struhl, K. 1995. Current protocols in molecular biology, New York: Wiley.

Bae, Y. S., Park, K. and Choi, O. H. 2007. Laboratory culture media-dependent biocontrol ability of Burkholderia gladioli strain B543. Plant Pathology J. 23:161-165.

Benhamou, N., Kloepper, J. W., Quadt-Hallman, A. and Tuzon, S. 1996. Induction of defense-related ultrastructural modification in pea root tissues inoculated with endophytic bacteria. Plant Physiol. 112:919-929.

Chung, Y. R., Sung, K. C., Mo, H. K., Son, D. Y., Nam, J. S., Chun, J. and Bae, K. S. 1999. Kitasatospora cheerisanensis sp. nov., a new species of the genus Kitasatospora that produces an antifungal agent. Int. J. Syst. Bacteriol. 49:753-758.

Compant, D., Duffy, B., Nowak., J., Clement., C., Barka, E. A. 2005. Use of plant growth-promoting bacteria for biocontrol of plant diseases: Principles, mechanisms of action, and future prospects. Appl. Environ. Microbiol. 71:4951-4959.

Elbeltagy, A., Nishioka, K., Sato, T., Suzuki, H., Ye, B., Hamada, T., Isawa, T., Mitsui, H. and Minamisawa, K. 2001. Endophytic colonization and in planta nitrogen fixation by a
Herbaspirillum sp. isoalted from wild rice species. Appl. Environ. Microbiol. 67:5285-5293.

Felsenstein, J. 1985. Confidence limits on phylogenies: an approach using the bootstrap. Evolution 39:783-791.

Fromin, N., Achouak, W., Thiery, J. M. and Heulin, T. 2001. The genotypic diversity of Pseudomonas brassicacearum populations isolated from roots of Arabidopsis thaliana: influence of plant genotype. FEMS Microbiol. Ecol. 37:21-29.

Garbeva, P., Overbeek, L. S., Vuurde, J. W. and Elsas, J. D. 2001. Analysis of endophytic bacterial communities of potato by plating and denaturing gradient gel electrophoresis (DGGE) of 16S rDNA based PCR fragments. Microb. Ecol. 41:369-383.

Goodfellow, M. and O'Donell, A. G. 1994. Chemical methods in prokaryotic systems. John Willey \& Sons, New York, N. Y., 575 pp.

Gurusiddaiah, S., Gealy, D. R., Kennedy, A. C. and Alex G. OGG., Jr. 1994. Isolation and characterization of metabolites from Pseudomonas fluorescens p-D7 for control of downy brom(Bromus tectorum). Weed Sci. 42:492-501.

Hall, T. A. 1999. BioEdit: a user-friendly biological sequence alignment editor and analysis program for Windows 95/98/ NT. Nucleic Acids Symp. Ser. 41:95-98.

Harrison, L. A., Letendre, L., Kovacevich, P., Pierson, E. and Weller, D. 1993. Purification of an antibiotic effective against Gaeumannomyces graminis var. tritici produced by a biocontrol agent, Pseudomonas aureofaciens. Soil Biol. Biochem. 25:215-221.

Kang, B. R., Song, H. H., Rob, E. Z., Anne, J. A., Matt, S., Kwang, Y. Y., Yong, H. K., Myung, C. L., Baik, H. C. and Young, C. K. 2007. Inhibition of seed germination and induction of systemic disease resistance by Pseudomonas chlororaphis $\mathrm{O} 6$ requires phenazine production regulated by the global regulator, GacS. J. Microbiol. Biotechnol. 17:586-593.

Kimura, M. 1983. The neutral theory of molecular evolution. Cambridge: Cambridge University Press.

Kuklinsky-Sorbal, J., Araujo, W. L., Mendes, R., Geraldi, I. O., Pizzirani-Kleiner, A. A. and Azevedo, J. L. 2004. Isolation and characterization of soybean-associated bacteria and their potential for plant growth promotion. Environ. Microbiol. 6:1244-1251.

Kumar, S., Tamura, K. and Nei, M. 2004. MEGA3: Integrated software for molecular evolutionary genetics analysis and sequence alignment. Brief Bioinform. 5:150-163.

Landa, B. B., Mavrodi, D. M., Thomashow, L. S. and Weller, D. M. 2003. Interactions between strains of 2,4-diacetylphloroglucinol-producing Pseudomonas fluorescens in the rhizosphere of wheat. Phytopathology 93:982-994.

McInroy, J. A. and Kloepper, J. W. 1995. Population dynamics of endophytic bacteria in field-grown sweet cron and cotton. Can. J. Microbiol. 41:895-901.

Misaghi, I. J. and Donndelinger, C. R. 1990. Endophytic bacteria in symptom-free cotton plants. Phytopathology 80:808-811.

Nejad, P. and Johnson, P. A. 2000. Endophytic bacteria induce growth promotion and wilt disease suppression in oil seed rape and tomat. Biol. Control 18:208-215.

Reddi, T. K., Khudyakov, Y. P. and Borovkov, A. V. 1969. 
Pseudomonas fluorescens strain 26-0, a producer of phytotoxic substances. Mikrobiologiya 38:909-913.

Rosenblueth, M. and Martinez-Romero, E. 2006. Bacterial endophytes and their interactions with hosts. Mol. Plant-Microbe. Intract. 19:827-837.

Ross, I. L., Alami, Y., Harvey, P. R., Achouak, W. and Ryder, M. H. 2000. Genetic diversity and biological control activity of novel species of closely related Pseudomonads isolated from wheat field soils in South Australia. Appl. Environ. Microbiol. 66:1609-1616.

Ryu, C. M., Farag, M. A., Hu, C. H., Reddy, M. S., Wei, H. X., Pare, P. W. and Kloepper, J. W. 2003. Bacterial volatiles promote growth in Arabidopsis. Proc. Nat. Acad. Sci. USA 100:4927-4935.

Saitou, N. and Nei, M. 1987. The neighbor-joining method: a new method for reconstructing phylogenetic trees. Mol. Biol. Evol. 4:406-425.

Shanahan, P., O'Sullivan, D. J., Simpson, P., Glennon, J. D. and Ogara, F. 1992. Isolation of 2,4-diacetylphloroglucinol from a fluorescent pseudomonad and investigation of physiological parameters influencing its production. Appl. Environ. Microbiol. 58:353-358.

Shanahan, P., Glennon, J. D., Crowley, J. J., Donnelly, D. F. and Ogara, F. 1993. Liquid chromatographic assay of microbially derived phloroglucinol antibiotics for establishing the biosynthetic route to production, and factors affecting their regulation. Anal. Chim. Acta 272:271-277.

Sikorski, J., Jahr, H. and Wackernagel, W. 2001. The structure of a local population of phytopathogenic Pseudomonas brassicacearum from agricultural soil indicates development under purifying selection pressure. Environ. Microbiol. 3:176-186.

Slininger, P. J., van Cauwenberge, J. E., Bothast, R. J., Weller, D.
M., Thomashow, L.S. and Cook, R. J. 1996. Effect of growth culture physiological state, metabolites, and formulation on the viability, phytotoxicity, and efficacy of the take-all biocontrol agent Pseudomonas fluorescens 2-79 stored encapsulated on wheat seeds. Appl. Microbiol. Biotechnol. 45:391-398.

Slininger, P. J. and Shea-Andersh, M. A. 2005. Proline-based modulation of 2,4-diacetylphloroglucinol and viable cell yields in cultures of Pseudomonas fluorescens wild-type and overproducing strains. Appl. Microbiol. Biotechnol. 68:630-638.

Sturz, A. V. and Christie, B. R. 1996. Endophytic bacteria of red clover as agents of allelopathic clover-maize syndromes. Soil Biol. Biochem. 28:583-588.

Suzuki, S., He, Y. and Oyaizu, H. 2003. Indole-3-acetic acid production in Pseudomonas fluorescens HP72 and its association with suppression of creeping bentgrass brown patch. Curr. Microbiol. 47:138-143.

Thomashow, L. S. and Weller, D. M. 1988. Role of a phenazine antibiotic from Pseudomonas fluorescens in biological control of Gaeumannomyces graminis var. tritici. J. Bacteriol. 170:3499-3508.

Thompson, J. D., Gibson, T. J., Plewniak, F., Jeanmougin, F. and Higgins, D. G. 1997. The CLUSTAL_X Windows interface: flexible strategies for multiple sequence alignment aided by quality analysis tools. Nucleic Acids Res. 25:4876-4882.

van Peer, R., Punte, H. L. M., de Wegger, L. A. and Schippers, B. 1990. Characterization of root surface and endorhizosphere pseudomonads in relation to their colonization of roots. Appl. Environ. Microbiol. 56:2462-2470.

Weller, D. M. 2007. Pseudomonas biocontrol agents of soilborne pathogens: Looking back over 30 years. Phytopathology 97:250-256. 